P Capriotti, I Zeler, A Oliveira (2019): "Dialogic communication 2.0. Analysis of interactions in Latin American organizations”. Revista Latina de Comunicación Social, 74, pp. 1094 to 1113. http://www.revistalatinacs.org/074paper/1373/56en.html DOI: 10.4185/RLCS-2019-1373en

\title{
Dialogic communication 2.0. Analysis of interactions in Latin American organizations
}

Paul Capriotti [CV] [ $\mathrm{ORCID}$ [ [ G GS] Full Professor of the Department of Communication Studies of Universitat Rovira i Virgili (URV), Spain paul.capriotti@urv.cat

Ileana Zeler [CV] [○ORCID] [ $[\underline{G S S}]$ Professor of the Department of Communication Studies of Universitat Rovira i Virgili (URV), Spain ileana.zeler@urv.cat (Corresponding author)

Andrea Oliveira [CV] [OORCID] [ G GS] Professor of the Department of Philology and Communication of Universitat de Girona (UdG), Spain andrea.oliveira@udg.edu

\begin{abstract}
Introduction. Social networks are key communication tools that enable organizations to engage in dialogue with their publics. Methodology. The objective is to determine, through content analysis, how Latin American organizations are using Facebook to foster dialogue with their publics. Results. Organizations have a prominent presence and a good level of activity on Facebook, but their interaction rate is low. Discussion and Conclusions. Organizations are using Facebook as a tool for disseminating information but not as a channel of communication with their publics; instead they maintain an unidirectional and non-dialogical approach. Their approach to communication focuses on increasing their visibility and fails to take advantage of the opportunities offered by social networks to generate and maintain relationships with their publics through dialogue and the exchange of information.
\end{abstract}

\section{Keywords}

Communication; Latin America; social networks; Facebook; organizations; engagement

\section{Contents}

1. Introduction. 1.1. Organizational communication in social networks. 1.2. Interaction management: from information to dialogue. 1.3. Content management: social and economic performance. 2. Methodology. 2.1. Selection of the sample of countries and companies. 2.2. Selection of the Facebook profiles and posts. 2.3. Research questions and categories of analysis. 2.4. Collection, systematization and data management. 3. Results. 3.1. Presence and activity. 3.2. Content. 3.3. Communication resources. 3.4. Interaction. 4. Discussion and conclusions. 5. List of References. 


\author{
Abstract translated by Christian Brassington \\ (Native English Translator-Linguistic Service-Universitat Rovira i Virgili) \\ Article translated by Yuhanny Henares \\ (Academic translator, Universitat de Barcelona)
}

\title{
1. Introduction
}

The use of social networks has increased recently, up to an extent that they have turned into a key instrument of organizational communication. Its prominent growth, access and popularity are introduced as an opportunity offered by Internet to communication professionals so to generate dialogue with publics (DiStaso, McCorkindale, \& Wright, 2011). This new professional reality requires the redefinition of communication strategies of organizations towards digital platforms.

The capacity to interact in a direct and close way with publics (Wang, 2015), as well as the possibility to generate enriching experiences, are aspects that encouraged organizations to use social networks (Linke \& Zerfass, 2012). The active and collaborative participation is relevant to develop relationships with publics. Sixto Garcia, Aguado Dominguez, \& Riveiro Castro (2017) maintain that besides generating interesting contents for users, organizations must be involved in a permanent and interactive manner in the digital area, fostering a fluent dialogue. Thus, social networks become a favourable channel for listening and active participation (Claes \& Deltell, 2013), and are being increasingly integrated to the communication programmes of organizations (Carim \& Warwick, 2013; DiStaso \& McCorkindale, 2013) and institutions (Giraldo-Luque, Villegas-Simón, \& Carniel Bugs, 2017).

To achieve a greater participation or visibility, it is necessary to understand social networks as an instrument of dialogue and interaction with publics. To generate dialogues between organizations and their publics, organizations must keep an adequate and professional presence in the social network. Thus, the level of presence and activity, the type of content disseminated, communication resources used, and interaction generated by organizations in the social network are essential elements for the effective management of communication with publics in the platform.

Social networks are also key instruments for the communication of Latin American companies. The change of organizational model promoted by the expansion and economic development of the region in the last decades, caused the need to increase the levels of trust and transparency. In this context, Latin American companies find in social networks, optimal tools to increase national and international visibility and to promote the dialogue with the publics (Moreno et al., 2017), to so to achieve a positive reputation.

Among social networks available, Facebook is presented as a key social network to potentiate the relationships between organizations and their publics. It has more than 2,000 million active users monthly around the world (Facebook, 2017). It is the social network of greater growth between 2014 and 2015 in Latin America (Fosk, 2015), one of the social networks preferred by Spanish and the most used to follow brands in Spain in 2016 (Interactive Advertising Bureau [IAB], 2016), and it is the network leading the ranking of most popular social networks in the United States (Duggan \& Page, 2015; Statista, 2018). Facebook offers organizations the possibility to disseminate key messages, share stories and have conversations.

Thus, in this study we aim to analyse how Latin American companies manage their dialogic communication 2.0 on Facebook. To do so, an analysis of the level of presence and activity in the social network was conducted, together with the main contents disseminated, the information resources used to spread contents through the social network and the level of interaction generated based on the disseminated contents. 


\subsection{Organizational communication in social networks}

Internet emerged as a new communication medium which use expanded rapidly worldwide (Shih, 2009). The great social penetration achieved by Internet significantly influenced in the relationship of organizations with their publics. This new space of communication caused a change in the traditional communication model. The so-called Web 2.0 modified the traditional communication model between organizations and their publics that characterised the beginnings of the Internet technology and facilitated the active participation of users (Kang \& Sundar, 2016). In the ecosystem 2.0, the users are able to disseminate contents, as well as to generate and intervene in conversations. Thus, the Web 2.0 turns into an open platform essentially based on the active participation of users, promoting the dialogic communication between organizations and their publics.

Despite that the Web 2.0 is the technology that makes room to the conversational, it is the social networks the ones that generate an optimum online communicational ecosystem for interactive and dialogic communication of organizations with their publics.

From the organizational perspective, social networks have turned into a key area of communication, up to the extent that they are increasingly integrating into the organizational communication strategies (Carim \& Warwick, 2013; Damásio, Dias, \& Andrade, 2012; DiStaso \& McCorkindale, 2013; Iniesta, 2012; Lee, 2016). Although professionals are acquiring knowledge and abilities in the digital world, the use of social networks as strategic management tool is still one of their main challenges. Chung, Andreev, Benyoucef, Duane, and O'Reilly (2017) state there is not yet a road map established to manage organizations' activities on social networks, but they are key strategical tools in organizations, since they entail a strong potential to revolution the way they interact with their publics.

From the publics' perspective, there are two aspects that influence directly in the active presence of companies in social networks. Firstly, because the publics are there. Almost $80 \%$ of Internet users access social networks (Kemp, 2018), and among their main motivations there is the social connection, shared identities, pictures, contents, social research, social network and status updates, entertainment, social interaction and information exchange (Jung \& Sundar, 2016; Valentini, 2015). Secondly, because users are having conversations about aspects of real life in social networks (in economic, political, social and cultural areas), and organizations are economic and social agents exposed on the digital ecosystem.

Facebook is the most popular among the social networks available. Based on the data of the Global Web Index 2016 and Digital in 2018, Facebook is the social network with the greatest number of active users worldwide (Kemp, 2018), of which more than half use their services at least once a day (Mander, 2016). Several authors agree that Facebook is being increasingly incorporated to the communication programmes of companies and their different organizational areas, in order to disseminate contents, listen actively, to participate in the conversation, and strengthen bonds with publics (Neill \& Moody, 2015).

There are studies that indicate that organizations are mostly becoming present on Facebook (Estudio de Comunicación, 2017; Ki \& Nekmat, 2014; Sixto Garcia et al., 2017), but their activity in the social network is rather scarce (Capriotti \& Losada-Díaz, 2018; Devaney, 2015; Quintly, 2016). According to experts and professionals, it is advisable to publish between 1 and 2 posts per day (Jordan, 2017; Patel, 2016). However, researches indicate that the activity of organizations on Facebook is less than 1 post per day (Altamirano Benitez, Marín-Gutiérrez, \& Ordóñez González, 2018; Devaney, 2015; Estudio de Comunicación, 2017; Kim, Kim, \& Hoon Sung, 2014; Quintly, 2016; Statista, 2017).

The adequate presence and activity on Facebook are key elements to reinforce bonds and relationships of trust between organizations and their publics. Thus, the first specific objective of this research consists of analysing the level of presence and activity that Latin American companies keep in this social network. 


\subsection{Interaction management: from information to dialogue}

The dialogic theory states that in order to guarantee effective relationships, organizations not only must disseminate information but also they must be willing to listen and interact with their publics (Taylor \& Kent, 2014). To do so, social networks provide an appropriate channel to promote interaction (Yang, Kang, \& Cha, 2015), at the same time that they become a relevant social capital that allow organizations to increase the value and visibility (Pérez-Dasilva et al., 2013), and Facebook in particular turns into a key instrument to establish and strengthen the dialogue with publics.

Jo and Kim (2003) state that interaction on social networks has significant effects in the construction of relationships between organizations and their publics, but this does not guarantee that the relationship is positive. To make this possible, it is necessary to establish long-term relationships of trust through dialogue.

On the one hand, to effectively communicate with their publics on social networks, organizations use different communication resources available: graphic resources (picture/image, text and emoticon), interactive resources (tag users and link and hashtag) and audiovisual resources (audio, video, and animated images). Different studies (Invodo, 2016; Pletikosa Cvijikj \& Michahelles, 2013; Quintly, 2016) indicate that the use of communication resources contributes to contents having a greater reach and interaction and that messages with an interactive approach generate a greater engagement in the public (Abitbol \& Lee, 2017). But studies point out that organizations are using Facebook to disseminate information (Huang, Lin \& Saxton, 2016; Shin, Pang \& Kim, 2015; Sundstrom \& Levenshus, 2017; Wissen, 2017), instead of fostering interaction.

Among the resources available on social networks, videos are the ones generating a greater level of engagement (Pletikosa Cvijikj \& Michahelles, 2013). Although recent studies indicate there is an exponential growth in the use of videos in Facebook (Serrano-Cobos, 2016), graphic resources are the most used by organizations to share contents (Capriotti \& Losada-Díaz, 2018; Luarn, Lin, \& Chiu, 2015), and their use in posts is twice higher than the audiovisual and interactive resources (Capriotti, Carretón, \& Castillo, 2016).

Thus, a second specific objective is proposed for this research, which consists of knowing what communication resources Latin American companies are using to present their contents on Facebook.

On the other hand, Facebook encourages organizations to communicate with greater closeness, easiness and fluency, and allow a direct connection between organizations and publics, to achieve a relationship of mutual benefit. This social network offers three forms of generating interactions: likes, shares and comments. Likes are a passive way to express appreciation of contents without verbal expression, shares allow users to be volunteer spokespersons of organizational messages in their own social groups, and comments allow users to stablish direct conversations with organizations and other users (Cho et al., 2014, cited in Abitbol \& Lee, 2017, p. 798).

Studies demonstrate that despite publics are more willing to keep interactions about contents promoting the dialogue and conversation (Cho et al., 2014), organizations and institutions are using social networks in general (Giraldo-Luque et al., 2017) and Facebook in particular to disseminate information (Capriotti \& Losada-Díaz, 2018; Huang et al., 2016; Shin et al., 2015; Sundstrom \& Levenshus, 2017; Wissen, 2017), not taking advantage of opportunities offered by social networks to interact, keep conversations, help and assist users. Thus, a third specific objective is presented that consists of determining the level and the rate of interaction generated from contents published by Latin American companies on Facebook.

\subsection{Content management: social and economic performance}

The way organizational attributes are presented and communicated through social networks influence the perceptions of the publics about the organization. There are studies that demonstrate that social networks present benefits for reputation (Floreddu, Cabiddu \& Evaristo, 2014; Li, Berens \& Maertelaere, 2013), and that the 
active participation of companies on social networks is related positively with the corporate reputation (Dijkmans \& Kerkhof, 2015).

The mental associations that publics build about an organization would be linked to two basic roles of organizations in society: the economic and social role (Carroll, 1999; Haigh, Brubaker, \& Whiteside, 2013; Waddock, 2004). The economic role is connected to the economic responsibilities of organizations to generate products and offer quality services, to comply with the law and obtain increasingly greater benefits. And the social role is connected to the social responsibilities of organizations so to comply with human rights, take care of the environment and provide a social contribution to the community (Berens \& Van Riel, 2004; Capriotti, 2009, 2012).

Eisenegger and Schranz (2011) and Lee (2016) state that the communication of social attributes can have a positive impact on the corporate reputation. However, studies state that contents disseminated by organizations on social networks are focused on economic responsibilities, instead of social responsibilities (Cho, Furey \& Mohr, 2016; Haigh et al., 2013).

Organizations mainly use social networks with advertising, promotional and marketing purposes (DiStaso et al., 2011; Kent, 2013; Macnamara, 2016; Valerio Ureña, Herrera Murillo, Herrera Murillo, \& Martínez Garza, 2015). There are studies that affirm that the interest for the brands, products, services is one of the factors driving users the most to follow companies on social networks, but the excess of promotional messages generates displease among users (Sprout Social, 2016). Thus, the fourth specific objective is to analyse what are the main contents (economic, social and of context) that Latin American companies disseminate on Facebook.

\section{Methodology}

The general objective of this research is to know how Latin American companies manage their dialogic communication 2.0 on Facebook.

\subsection{Selection of the sample of countries and companies}

To identify the main economies of Latin America, there were selected the countries with a higher Gross Domestic Product (GDP) and where there was conducted the annual study of corporate reputation called Monitor Empresarial de Reputación Corporativa (MERCO) [Company Monitor on Corporate Reputation], for at least two years (2013 and 2014). The final sample is constituted by the 6 following countries: Brazil, Mexico, Argentina, Colombia, Chile and Peru.

To select companies, those having a better corporate reputation in Latin America were selected, since they were considered a reference on communication management issues, at the same time they were the ones allocating relevant resources to innovate and to be in the forefront on digital communication.

Thus, the annual study on corporate reputation mercoEmpresas by MERCO was taken as a reference and there were considered the first 35 companies in said ranking during 2013 and 2014 from Brazil, Mexico, Argentina, Colombia, Chile and Peru.

From the total sample, it was decided to discard from the sample those companies corresponding to the Media sector, considering there were already studies that demonstrated there is the tendency to use social networks by traditional media (press, radio and television), as a dissemination platform of news (Escalas Ribas, 2014; GarcíaDe-Torres et al., 2011; Noguera Vivo, 2010). Also, universities were discarded, since they do not meet thematic and contents variables established for the specific analysis of companies, either public or private. Thus, the final sample included 157 companies of Latin America (27 from Brazil, 23 from Mexico, 26 from Argentina, 30 from Colombia, 23 from Chile and 28 from Perú). 


\subsection{Selection of the Facebook profiles and posts.}

To select Facebook profiles there were considered the companies having "official" corporate fanpages on Facebook at national scope, also considering that in addition to national companies, there are multinational companies with presence in Latin America.

The corporate profiles were localized initially through the direct links to Facebook present in the official websites of the companies. There were discarded all the profiles that could not be located through the popular Internet browsers or verified by the companies.

Thus, the final sample of Facebook profiles in 2015 and 2016 included 135 profiles of companies operational in Latin America (25 from Brazil, 19 from Mexico, 23 from Argentina, 27 from Colombia, 19 from Chile and 22 from Peru).

To determine the volume of posts analysed, a selection of temporal periods was done. There were collected all posts of the odd weeks in 2015 (from January until June), and the even weeks in 2016 (from July until December). Finally, 29,078 posts were obtained.

\subsection{Research questions and categories of analysis}

To fulfil the main goal of this study, 4 research questions were formulated (RQ):

RQ1: Do companies have corporate profiles on Facebook? If so, what is their level of presence and activity in the social network?

RQ2: What are the main contents that companies disseminate through Facebook?

RQ3: What are the communication resources companies use to disseminate their contents through Facebook?

RQ4: What kind of interaction is generated from contents published by companies on Facebook?

To answer the research questions, the quantitative methodology of content analysis was used to analyse the Facebook profiles and there were defined 4 categories based on the presence and activity, content, information resources and interaction. The categories of analysis presented were developed and tested in previous studies (Capriotti et al., 2016; Losada-Díaz \& Capriotti, 2015).

Table 1 Category: Presence and activity

\begin{tabular}{lll}
\hline Categories & Dimensions & Aspects \\
\hline Presence & Type of page & Corporate fanpage \\
& & User profile \\
& Institutional information & Extended \\
& & Brief \\
\hline Activity & Level of activity & Total general \\
& & Daily average \\
& Weekly average
\end{tabular}

Source: Authors' own elaboration 
For RQ1, a category of Presence and Activity, was established that allows to identify and characterise profiles developed by companies on the social network (Table 1). To do so, 3 dimensions of analysis were established (two of presence and one of activity): the type of page (corporate fanpage or user profile); institutional information (whether it is extended or brief); and the level of activity (obtained from the total general and the daily, weekly average of posts from companies).

For RQ2, the category of Content was established, which allows to identify the main themes managed by companies. To do so, 3 key dimensions were identified: (a) Business topics: themes related to corporate, commercial and business activities of companies; (b) CSR topics: themes dealing with the CSR of the company in its daily activities; and (c) Context topics: themes related to the general and business sector context of the company (Table 2).

Table 2 Category: content

\begin{tabular}{lll}
\hline Categories & Dimensions & Aspects \\
\hline Content & Business topics & Strategy, results, offer, innovation \\
& CSR topics & Integrity, work and citizenship \\
& Context topics & General, sector-related and relational \\
\hline
\end{tabular}

Source: Authors' own elaboration

For RQ3, the category Communication Resources was established that allows to determine the resources used for the dissemination of contents. Thus, 2 key dimensions were selected: (1) Format: defines the use of graphic (text, image, emoticon), audiovisual (animated images, audio-video), and interactive resources (link, hashtag, tag users). (2) Approach: analyses contents disseminated from 2 types of communicational approaches: (a) informational: aims to boost the diffusion of information for public knowledge, (b) interactive: encourages to participate, share, go to the store, provide a suggestion or opinion, etc. (Table 3).

Table 3 Category: Communication resources

\begin{tabular}{lll}
\hline Categories & Dimensions & Resources \\
\hline Information resources & Format & Graphic \\
& & Audiovisual \\
& Approach & Interactive \\
& & Informational \\
& Interactive \\
\hline
\end{tabular}

Source: Authors' own elaboration

For RQ4, the Interaction category was established, which allows to analyse the interactivity generated by contents published in Facebook users. To do so, 2 aspects to analyse were detected: the level of engagement and the engagement rate. On the one hand, the level of engagement allows to assess the volume of reactions 
generated by the posts disseminated by companies. To analyse the level of engagement 3 elements were considered: (a) Likes: total number of "likes" obtained in publications; (b) Shares: total number of times the publication was shared; (c) Comments: number of comments from companies and users in publications. On the other hand, the engagement rate allows to assess the volume of reactions generated by posts in relation to number of followers from companies. To evaluate the engagement rate 3 indicators were established: support rate (TdA) estimated from the total of likes divided by the total number of fans, $\mathrm{x} 100$; the viralization rate (TdV) estimated from the total of shares divided by the total number of fans, $\mathrm{x} 100$; and the conversation rate (TdC) estimated from the total of comments divided by the total number of fans, $\mathrm{x} 100$ (Kaushik, 2011; Narayanan et al., 2012). To obtain the TEG, the results of TdA, TdV and TdC were summed (Table 4).

Table 4 Category: Interaction

\begin{tabular}{lll}
\hline Categories & Dimension & Aspects \\
\hline Interaction & Level of engagement & Total Mean of posts likes \\
& Total Mean of posts shares \\
& Total Mean of posts comments \\
& Support rate (TdA) \\
& Viralization rate (TdV) \\
& Conversation rate (TdC) \\
& General Engagement Rate (TEG)
\end{tabular}

Source: Authors' own elaboration

\subsection{Collection, systematization and data management.}

The proposal of analysis categories allowed the design of an analysis template made on Excel, were the collected data of the sample were entered and codified. For the data collection, a paid monitoring tool available on Internet was used, called FanPage Karma, which allows to gather posts from companies and offers detailed analysis depending on content and engagement.

\section{Results}

The results are presented based on research questions (RQ).

\subsection{Presence and activity}

Regarding the presence and activity (RQ1), mostly companies have corporate pages on Facebook, but only two thirds of fanpages have adequate institutional information. On the other hand, its activity is rather frequent on the studied social network.

The presence of Latin American companies on Facebook is about 86\% (Table 5). Although Argentina, Brazil and Colombia have a lot of presence (more than 85\%), it is detected that Mexican companies have a presence that hardly exceeds $70 \%$ of the total, and Chile, Peru and Mexico position below the mean (around $80 \%$ ). 
Most companies of Latin America show a correct and extended institutional information on their Facebook profiles $(67.4 \%)$, namely they have information related to the mission, vision, objectives, milestones that contribute to the organizational identity, location and contact data, etc.

Latin-American companies, mostly, show a correct and extended institutional information in their Facebook profiles $(67.4 \%)$, namely they have information related to the mission, vision, goals and milestones that contribute to organizational identity, location and contact data, etc.

The results of Latin American countries are presented in a similar way. In almost all cases there is detected that around $60 \%$ of fanpages have a wide organizational information (Table 5). However, Mexico is the country with the greatest percentage of companies with a broad institutional information on Facebook $(73.7 \%)$.

Table 5 Presence of companies on Facebook

\begin{tabular}{lccccccc}
\hline Presence & $\begin{array}{c}\text { Latin } \\
\text { America }\end{array}$ & Argentina & Brazil & Chile & Colombia & Mexico & Peru \\
\hline \multicolumn{7}{c}{ Corporate Fanpages (in \%) } \\
\hline Yes & 86.5 & 88.5 & 92.6 & 82.6 & 90.0 & 82.6 & 78.6 \\
No & 13.5 & 11.5 & 7.4 & 17.4 & 10.0 & 17.4 & 21.4 \\
\hline & 67.4 & 60.9 & 68.0 & 63.2 & 70.4 & 73.7 & 68.2 \\
\hline Extended & 32.6 & 39.1 & 32.0 & 36.8 & 29.6 & 26.3 & 31.8 \\
Brief & \multicolumn{7}{c}{ Institutional Information (\%) } \\
\hline
\end{tabular}

Source: Authors' own elaboration

Regarding activity, companies publish contents very often in their corporate fanpages, about 1.2 posts per day (Table 6).

The difference in the activity per country is not so relevant, except for Chile. Although this country is the second with the lowest presence of companies in the social network, the results show it is the country with more activity on Facebook (almost 2 posts per day per company).

Table 6 Activity of companies on Facebook

\begin{tabular}{lccccccc}
\hline Activity & $\begin{array}{c}\text { Latin } \\
\text { America }\end{array}$ & Argentina & Brazil & Chile & Colombia & Mexico & Peru \\
\hline Total general & 29,078 & 4,456 & 4,361 & 6,015 & 6,129 & 4,089 & 4,028 \\
Daily average & 1.2 & 1.1 & 1 & 1.8 & 1.3 & 1.3 & 1 \\
Monthly average & 8.4 & 7.5 & 7 & 12.2 & 8.7 & 8.7 & 6.9 \\
\hline
\end{tabular}

Source: Authors' own elaboration 


\subsection{Contents}

Regarding the results about contents (RQ2), companies are mainly focused on the dissemination of business topics (about 60\%). CSR and context topics are spread 3 times less than the former (about $20 \%$ in both cases), (Table 7). Regarding business topics, companies deal with their commercial aspects with greater relevance (products and services offer). And regarding the CSR topics, there is focus on the dissemination of their social and environmental responsibilities.

Regarding the results of the Latin American countries, it is observed that all are mainly focused on business topics. This represents between $50 \%$ and $60 \%$ of publications in almost all countries, except for Argentina, where the presence of posts about business topics represents a quite higher percentage compared to the rest of countries $(74.1 \%)$.

Table 7 Types of communication disseminated by companies on Facebook (\%)

\begin{tabular}{lccccccc}
\hline Content & $\begin{array}{c}\text { Latin } \\
\text { America }\end{array}$ & Argentina & Brazil & Chile & Colombia & Mexico & Peru \\
\hline Business & 57.8 & 74.1 & 60.2 & 55.5 & 56.3 & 50.9 & 49.9 \\
CSR & 19.6 & 10.9 & 18.7 & 17.5 & 23.5 & 27.5 & 19.7 \\
Context & 22.6 & 15.0 & 21.1 & 27.0 & 20.2 & 21.6 & 30.4 \\
\hline
\end{tabular}

Source: Authors' own elaboration

\subsection{Communication Resources}

The results of communication resources (RQ3) show significant differences. Regarding format, graphic resources are the most used by companies to disseminate contents on Facebook (Table 8). Almost the entirety of posts have text $(97.8 \%)$, and the fixed images are selected to accompany it the most. In some cases, emoticons are included as well (less than 10\%). On the other hand, it has been detected that audiovisual resources are the least used in contents. Somewhat more than $10 \%$ of posts have videos $(12.7 \%)$ or animated images $(9.8 \%)$.

Also, interactive resources are used such as links and hashtags. Even though their presence in posts is lower compared to graphic resources, at least half of posts have one or more interactive resources, therefore they are used more than audiovisual resources.

Comparing the different Latin American countries, all of them mainly use graphic resources (text and image). However, a significant difference in the use of audiovisual resources between Brazil, Mexico and Chile is noteworthy. Even though the use of videos is not so frequent in general, companies with operations in Brazil and Mexico are the ones using this resource the most (about 15\%), and the Chilean companies are the ones using it the least (less than 10\%). On the other hand, Brazilian companies are the ones using interactive resources the most. Almost 70\% of posts from Brazil have a link, which represents between 15\% and 25\% more compared to the rest of countries. 
Table 8 Communication resources used by companies on Facebook (\%)

\begin{tabular}{lccccccc}
\hline Communication resources & $\begin{array}{c}\text { Latin } \\
\text { America }\end{array}$ & Argentina & Brazil & Chile & Colombia & Mexico & Peru \\
& \multicolumn{7}{c}{ Format (\%) } \\
\hline Graphic resources & 97.8 & 96.8 & 97.3 & 98.3 & 97.5 & 97.9 & 98.8 \\
Interactive resources & 48.6 & 51.7 & 64.3 & 53.6 & 43.7 & 40.9 & 45.5 \\
Audiovisual resources & 12.7 & 12.3 & 15.1 & 13.0 & 11.8 & 16.8 & 14.1 \\
\hline & 74.0 & 71.5 & 75.0 & 71.6 & 76.5 & 78.0 & 71.4 \\
\hline Informational & 26.0 & 28.5 & 25.0 & 28.4 & 23.5 & 22.1 & 28.6 \\
Interactive & \multicolumn{7}{c}{ Approach (\%) } \\
\hline
\end{tabular}

Source: Authors' own elaboration

About the approach, it is observed on Table 8 that posts mostly have an informational approach. More than $70 \%$ of posts disseminate information in order to make public what companies do and think. This means that less than 30\% of posts have an interactive approach and promote that users perform some kind of action, either participating, provide an opinion or a suggestion, etc. These results are similar in all countries of Latin America.

\subsection{Interaction}

The results about interaction (RQ3) show it is rather low. Regarding the level of engagement, the level of support $(88.5 \%)$ is quite above the level of viralization (7.5\%) and conversation (4\%) (Table 9). According to the data obtained, by every 12 likes a post gets, it is shared just once, and by every 25 likes, a post receives at least one comment from users. It is worth mentioning that users show much more interested than companies in interacting and having conversations about the contents of posts disseminated by companies: almost the entirety of comments found correspond to those made by users (3.5\% out of the total $4 \%$ ).

There is a scarcely significant difference among Latin American countries. In all cases, the level of support is much higher that the level of viralization and conversation. However, it is worth mentioning there is a significant difference in the average of likes per country, being Brazil the country that most likes receives per post per company (a mean of 3,637.6). Likewise, these results are observed in the obtained data about shares. Every post per company of Brazil is shared about 270 times, widely exceeding the average of shares of Latin America (106.6 per company per post). In addition, on results it is also detected that Colombia and Chile are the countries that fewer likes and shares get per post. Data show that every post per company of Colombia gets somewhat more than 390 likes and it is shared about 60 times. And data from Chile indicate that every post per company receives 316 likes and it is shared 23 times. Compared to this, it is also observed that Colombia is the country obtaining the highest percentage of shares (almost 13\%).

About the level of conversation, it is detected that the total percentage of comments does not exceed the 5.5\% from the total of interactions. Likewise, there is a significant difference between comments of Latin America and Brazil, being this country the one that most comments from users gets per post per company (121.8). In addition, there are also countries that receive very few comments from users (Colombia and Mexico). For instance, Colombia is the country showing the lowest average of comments per post per company of Latin America (14.5), followed by Mexico with an average of somewhat more than 30 comments per post per 
company. In general, comments from users are quite above the average of comments from companies, therefore the greatest commitment comes from users. Regarding comments from companies, the percentage is very low in all countries (in almost all cases it does not exceed 1\%). However, it is worth mentioning that the mean of Peru is the highest among all countries and it reaches the 15 comments of companies per post. This means that companies of Perú are the ones that intervene the most in conversations (Table 9).

Table 9 Level of engagement of companies on Facebook

\begin{tabular}{|c|c|c|c|c|c|c|}
\hline \multirow[t]{2}{*}{$\begin{array}{l}\text { Level of } \\
\text { engagement }\end{array}$} & & \multirow{2}{*}{$\begin{array}{c}\text { Level of } \\
\text { support } \\
\text { (likes) }\end{array}$} & \multirow{2}{*}{$\begin{array}{l}\text { Level of } \\
\text { viralization } \\
\text { (shares) }\end{array}$} & \multicolumn{3}{|c|}{$\begin{array}{l}\text { Level of conversation } \\
\text { (comments) }\end{array}$} \\
\hline & & & & Total & Companies & Users \\
\hline \multirow{2}{*}{$\begin{array}{l}\text { Latin } \\
\text { America }\end{array}$} & Mean/comp/post & $1,265.9$ & 106.6 & 56.8 & 6.8 & 50.1 \\
\hline & $\%$ total & 88.5 & 7.5 & 4.0 & 0.5 & 3.5 \\
\hline \multirow{2}{*}{ Argentina } & Mean/comp/post & $1,323.8$ & 85.3 & 63.3 & 5.6 & 57.7 \\
\hline & $\%$ total & 90.3 & 5.3 & 4.4 & 0.4 & 4.0 \\
\hline \multirow{2}{*}{ Brazil } & Mean/comp/post & $3,637.6$ & 272.9 & 121.8 & 11.1 & 110.6 \\
\hline & $\%$ total & 90.2 & 6.8 & 3.0 & 0.1 & 2.9 \\
\hline \multirow{2}{*}{ Chile } & Mean/comp/post & 316.0 & 23.2 & 49.3 & 2.2 & 47.2 \\
\hline & $\%$ total & 81.3 & 6.0 & 12.7 & 0.6 & 12.1 \\
\hline \multirow{2}{*}{ Colombia } & Mean/comp/post & 390.5 & 59.7 & 17.0 & 2.5 & 14.5 \\
\hline & $\%$ total & 83.6 & 12.8 & 3.6 & 0.5 & 3.1 \\
\hline \multirow{2}{*}{ México } & Mean/comp/post & $1,547.6$ & 179.8 & 40.2 & 7.8 & 32.4 \\
\hline & $\%$ total & 85.3 & 9.9 & 4.8 & 0.4 & 4.4 \\
\hline \multirow{2}{*}{ Perú } & Mean/comp/post & $1,098.8$ & 71.6 & 68.2 & 15.6 & 52.6 \\
\hline & $\%$ total & 88.7 & 5.8 & 5.5 & 1.3 & 4.2 \\
\hline
\end{tabular}

Source: Authors' own elaboration

Even though the results about level of engagement show there is a high volume of interaction, it is necessary to emphasize that companies have a high average of followers.

In this sense, the results of the engagement rate show that interaction generated about contents by every 100 fans is rather low (Table 10). The data obtained indicate that the TdA is the one showing a greater percentage (5.7\% annually). This result exceeds the one obtained by $\mathrm{TdV}$ and $\mathrm{TdC}$ by far (both show percentages below $1 \%$ annually). 
In all Latin American countries, the greater percentage corresponds to $\mathrm{TdA}$, followed by $\mathrm{TdV}$ and $\mathrm{TdC}$. However, there are countries like Argentina, Chile, Colombia, Peru and Mexico which TdA reaches between $10 \%$ and $15 \%$ per company per year compared to the annual TdA of Latin America (5.7\%).

The general engagement rate (TEG) obtained is $6.5 \%$ per company per year. There is an outstanding difference between the TEG per countries of Latin America, since it is detected that in Argentina and Colombia (17\%), as well as Chile and Peru it is 14\%, and Mexico is 15.5, the TEG per company is 2 or 3 times higher than that of Latin America (Table 10). On the other hand, Brazil is the country that less TEG obtains per company (somewhat higher than 3\%).

Table 10 Engagement Rate of companies on Facebook (\%)

\begin{tabular}{lcccc}
\hline $\begin{array}{l}\text { Engagement rate } \\
\text { by every 100 fans } \\
(\%)\end{array}$ & $\begin{array}{c}\text { Support rate } \\
(\mathrm{TdA})\end{array}$ & $\begin{array}{c}\text { Viralization rate } \\
(\mathrm{TdV})\end{array}$ & $\begin{array}{c}\text { Conversation rate } \\
(\mathrm{TdC})\end{array}$ & $\begin{array}{c}\text { General } \\
\text { Engagement Rate } \\
(\mathrm{TEG})\end{array}$ \\
\hline Latin America & 5.7 & 0.5 & 0.3 & 6.5 \\
Argentina & 14.8 & 1.0 & 1.4 & 17.2 \\
Brazil & 3.2 & 0.2 & 0.1 & 3.5 \\
Chile & 11.6 & 0.8 & 1.8 & 14.2 \\
Colombia & 14.5 & 2.2 & 0.6 & 17.3 \\
Mexico & 13.2 & 1.5 & 0.7 & 15.4 \\
Peru & 12.5 & 0.8 & 0.8 & 14.1 \\
\hline
\end{tabular}

Source: Authors' own elaboration

\section{Discussion and conclusions}

Regarding the "presence and activity" (RQ1), the study shows that the main companies of Latin America have a majoritarian presence on Facebook (more than 85\%). However, it must be emphasized that only a little bit more than two thirds of companies present on Facebook have a correct presence in the social network (67.4\%).

The companies present on the social network have a good level of activity. According to the recommendation of experts and professionals, it is ideal to publish between 1 and 2 posts per day (Jordan, 2017; Patel, 2016). The results of this study indicate that companies have a minimally adequate level of activity. These findings are similar to those obtained by other studies (Capriotti \& Losada-Díaz, 2018; Estudio de Comunicación, 2017; Kim et al., 2014).

Regarding the "contents" disseminated on the social network (RQ2), the topics are mainly focused on business, specifically the commercial offer. These results are aligned with those of previous studies that indicate that contents of companies are focused on business (Eisenegger \& Schranz, 2011; Haigh et al., 2013) and that social networks are used for promotion and advertising (Parveen, Jaafar, \& Ainin, 2014), instead of having dialogues about aspects linked to CSR. Despite the fact that social networks are relevant tools for the communication of 
CSR, since they allow to promote and strengthen reputation (Cortado \& Chalmeta, 2016), the research results show that in very few occasions companies are using Facebook to communicate their CSR.

Regarding the category "communication resources" (RQ3), most companies include graphic resources in their contents. Even though almost all posts have text and fixed image, it is also found that more than half of posts promote interaction through the use of links and hashtags. This suggests that companies are also using interactive resources with a certain frequency to foster interaction with users on Facebook. However, audiovisual resources are the least used, although they contribute to increase the engagement even more because they involve a greater level of commitment (Pletikosa Cvijikj \& Michahelles, 2013; Quintly, 2016). But this study shows that companies are not taking advantage of videos and animated images to generate a greater engagement. Likewise, the communicational approach used to disseminate contents is essentially informative. In few occasions Facebook is used to encourage users to generate interactions. Even though a wide percentage of companies includes interactive and audiovisual resources in posts, in few occasions they elaborate messages encouraging users to issue opinions, participate or get involved in some activity.

The results about "interaction" (RQ4), indicate there is a great volume of interaction on contents disseminated by companies, but the level of interactions is mainly determined by the high volume of "likes" obtained. The level of viralization (shares) and conversation (comments) are much lower than the level of support (likes). This result is reflected in the TEG. Although likes are very used, the level of commitment that this kind of interaction involves is much lower than the levels generated by shares or comments, therefore the TEG is low.

The results about the engagement rates indicate there is a very low percentage of users that interact with company updates, therefore the participation by users in general is rather poor. This suggests that companies are disseminating information that is scarcely interesting for users or that are showing quite little interest in generating and keeping the dialogue with publics on the social network. According to the data about the conversation rate, in very few occasions companies respond to user's comments.

In conclusion overall, it can be said that the main Latin American companies have an outstanding presence on Facebook, although their level of activity is minimally adequate and can be improved. Companies focus their communication mainly in the dissemination of business contents, leaving the CSR topics aside. In addition, the social networks are scarcely harnessed to promote interaction and keep dialogues with the publics. This allows to reaffirm that companies are missing a purpose of communication through Facebook, which is to generate and maintain relationships with users through dialogue. In this sense, it is possible there are two reason why companies are not keeping dialogues with their publics in an adequate manner. On the one hand, due to the lack of resources or having limited resources (Wissen, 2017), which is rather unlikely in this research, since companies studied are large corporations. And on the other hand, due to fear of losing control of conversations with publics (van den Berg \& Verhoeven, 2017), which would hardly be a strategical thinking, since the fact that companies participate in conversations and dialogue with users allows to increase trust and achieve a greater commitment by publics, at the same time it contributes to strengthen their corporate reputation.

Since the moment that companies include Facebook in their communication strategies, they start to use a key tool to generate relationships with their publics in the online ecosystem. To do so, to keep a correct presence, a frequent level of activity and a high level of interaction contribute to achieve a successful management of communication with their publics. Through the production of quality contents and the adequate use of resources, a greater interaction and dialogue with publics can be achieved. However, companies are using Facebook as another dissemination channel rather than a communication channel. Despite they have a significant number of followers interested in their contents, companies are not managing communication with publics on Facebook to stablish and strengthen relationships, but rather to achieve visibility. 
Finally, this study presents a specific methodology to analyse the management of communication on Facebook and it was adapted to a specific object of study (companies). From the academic perspective, the study can be useful for application in other sorts of organizations (for instance, non-profit organizations and/or public institutions), and also in countries and/or specific regions and promote the comparative analysis, that allows to determine whether the tendencies and results found are replicated in other kinds of organizations and geographical areas. From the professional perspective, the results can contribute to detect strengths and weaknesses of the management of communication on social networks, and thus improve the practices in organizations.

\section{List of references}

Abitbol, A., \& Lee, S. Y. (2017). Messages on CSR-dedicated Facebook pages: What works and what doesn't. Public Relations Review, 43(4), 796-808. http://doi.org/10.1016/j.pubrev.2017.05.002

Altamirano Benitez, V., Marín-Gutiérrez, I., \& Ordóñez González, K. (2018). Comunicación turística 2.0 en Ecuador. Análisis de las empresas públicas y privadas. Revista Latina de Comunicación Social, 73, 633-647. http://doi.org/10.4185/RLCS-2018-1273

Berens, G., \& Van Riel, C. B. M. (2004). Corporate Associations in the Academic Literature: Three Main Streams of Thought in the Reputation Measurement Literature. Corporate Reputation Review, 7(2), 161-178. http://doi.org/10.1057/palgrave.crr.1540218

Capriotti, P. (2009). Economic and Social Roles of Companies in the Mass Media: The Impact Media Visibility Has on Businesses' Being Recognized as Economic and Social Actors. Business \& Society, 48(2), 225-242. http://doi.org/10.1177/0007650307305724

Capriotti, P. (2012). Las Vegas en Los Monegros: Evaluating the mass media coverage of the social and economic impact of a business project from a corporate communication perspective. Estudios Sobre El Mensaje Periodistico, 18(1), 305-320. http://doi.org/10.5209/rev_ESMP.2012.v18.n1.39372

Capriotti, P., Carretón, C., \& Castillo, A. (2016). Testing the level of interactivity of institutional websites: From museums 1.0 to museums 2.0. International Journal of Information Management, 36(1). http://doi.org/10.1016/j.ijinfomgt.2015.10.003

Capriotti, P., \& Losada-Díaz, J. C. (2018). Facebook as a dialogic communication tool at the most visited museums of the world. El Profesional de La Informacion, 27(3).

Carim, L., \& Warwick, C. (2013). Use of social media for corporate communications by research-funding organisations in the UK. Public Relations Review, 39(5), 521-525.

http://doi.org/10.1016/j.pubrev.2013.08.006

Carroll, A. B. (1999). Corporate social responsibility. Business and Society, 38(3), 268-295.

http://doi.org/https://doi.org/10.1177/000765039903800303

Cho, M., Furey, L., \& Mohr, T. (2016). Communicating Corporate Social Responsibility on Social Media: Strategies, Stakeholders, and Public Engagement on Corporate Facebook. Business and Professional Communication Quarterly, 80(1), 52-69. http://doi.org/10.1177/2329490616663708

Cho, M., Schweickart, T., \& Haase, A. (2014). Public engagement with nonprofit organizations on Facebook. Public Relations Review, 40(3), 565-567. http://doi.org/10.1016/j.pubrev.2014.01.008

Chung, A. Q. H., Andreev, P., Benyoucef, M., Duane, A., \& O’Reilly, P. (2017). Managing an organisation's 
social media presence: An empirical stages of growth model. International Journal of Information Management, 37(1), 1405-1417. http://doi.org/10.1016/j.ijinfomgt.2016.10.003

Claes, F., \& Deltell, L. (2013). Museos Sociales. Perfiles Museísticos en Twitter y Facebook 2012-2013. El Profesional de La Informacion, 23(6), 594-602. http://doi.org/10.3145/epi.2014.nov.06

Cortado, F. J., \& Chalmeta, R. (2016). Use of social networks as a CSR communication tool. Cogent Business \& Management, 3(1), 1187783. http://doi.org/10.1080/23311975.2016.1187783

Damásio, M. J., Dias, P., \& Andrade, J. G. (2012). The PR Pyramid : Social media and the new role of Public Relations in organizations. Revista Internacional de Relaciones Públicas, 2(4), 11-30. http://doi.org/http://dx.doi.org/10.5783/RIRP-4-201201-11-30

Devaney, E. (2015). Social Media Benchmarks Report • 2015. Retrieved from https://cdn2.hubspot.net/hub/53/file-2415418647-pdf/00-OFFERS-HIDDEN/social-media-benchmarks2015.pdf?t=1423113374840

Dijkmans, C., \& Kerkhof, P. (2015). Online Conversation and Corporate Reputation : A Two-Wave Longitudinal Study on the Effects of Exposure to the Social Media Activities of a. Journal of ComputerMediated Communication, 20, 632-648. http://doi.org/10.1111/jcc4.12132

DiStaso, M. W., \& McCorkindale, T. (2013). A Benchmark Analysis of the Strategic Use of Social Media for Fortune's Most Admired U.S. Companies on Facebook, Twitter and Youtube. Public Relations Journal, 7(1), $1-33$.

DiStaso, M. W., McCorkindale, T., \& Wright, D. K. (2011). How public relations executives perceive and measure the impact of social media in their organizations. Public Relations Review, 37(3), 325-328. http://doi.org/10.1016/j.pubrev.2011.06.005

Duggan, M., \& Page, D. (2015). Mobile Messaging and Social Media 2015. Pew Research Center, pp. 1-20. Retrieved from http://www.pewinternet.org/2015/08/19/mobile-messaging-and-social-media-2015/

Eisenegger, M., \& Schranz, M. (2011). Reputation Management and Corporate Social Responsibility. In Ø. Ihlen, J. L. Bartlett, \& S. May (Eds.), The handbook of Communication and Corporate Social Responsibility (pp. 129-146). Sussex: Wiley-Blackwell.

Escalas Ribas, A. M. (2014). Relaciones entre las principales redes sociales y los medios de comunicación en España. Una revisión al estado de la cuestión. TecCom Studies, 5, 104-113.

Estudio de Comunicación. (2017). Presencia de las empresas del Ibex 35 en el entorno digital. Tercera edición. Retrieved 21 February 2017, from http://www.estudiodecomunicacion.com/extranet/portfolioview/presencia-de-las-empresas-del-ibex35-en-el-entorno-digital/

Facebook. (2017). Facebook newsroom: Company Info. Retrieved 10 July 2017, from http://newsroom.fb.com/company-info/

Floreddu, P. B., Cabiddu, F., \& Evaristo, R. (2014). Inside your social media ring: How to optimize online corporate reputation. Business Horizons, 57(6), 737-745. http://doi.org/10.1016/j.bushor.2014.07.007

Fosk, A. (2015). Futuro Digital LATAM 2015. ComScore. Retrieved from http://www.comscore.com/lat/FuturoDigital2015 
García-De-Torres, E., Yezers'ka, L., Rost, A., Calderí-n, M., Edo, C., Rojano, M., ... Corredoira, L. (2011). Uso de Twitter y Facebook por los medios iberoamericanos. El Profesional de La Informacion, 20(6), 611620. http://doi.org/10.3145/epi.2011.nov.02

Giraldo-Luque, S., Villegas-Simón, I., \& Carniel Bugs, R. (2017). ¿Cómo usan los parlamentos las redes sociales? Un estudio comparado y longitudinal aplicado a países de América y Europa (2010, 2015 y 2017). Revista Latina de Comunicación Social, 72, 1.278-1.299. http://doi.org/10.4185/RLCS-2017-1219

Haigh, M. M., Brubaker, P., \& Whiteside, E. (2013). Facebook: examining the information presented and its impact on stakeholders. Corporate Communications: An International Journal, 18(1), 52-69. http://doi.org/10.1108/13563281311294128

Huang, Y.-C., Lin, Y., \& Saxton, G. D. (2016). Give Me a Like: How HIV/AIDS Nonprofit Organizations Can Engage Their Audience on Facebook. AIDS Education and Prevention, 28(6), 539-556. http://doi.org/10.1007/s10551-015-2769-z.For

Iniesta, C. R. (2012). El uso de las herramientas digitales por parte de los bancos. El caso de la imagen en Internet de Banco Santander y BBVA en época de crisis. Revista Internacional de Relaciones Públicas, II, $51-72$.

Interactive Advertising Bureau. (2016). Estudio anual de Redes Sociales. Madrid. Retrieved from http://www.iabspain.net/wpcontent/uploads/downloads/2016/04/IAB_EstudioRedesSociales_2016_VCorta.pdf

Invodo. (2016). Video Statistics. The Marketer's Summary 2016. Retrieved from http://www.invodo.com/thank-you/thank-you-2016-video-statistics/

Jo, S., \& Kim, Y. (2003). The Effect of Web Characteristics on Relationship Building. Journal of Public Relations Research, 15(3), 199-223. http://doi.org/10.1207/S1532754XJPRR1503_1

Jordan, R. (2017). How Frequently Should I Post to Facebook? — Rachel B Jordan. Retrieved 21 June 2017, from http://www.rachelbjordan.com/marketing-leadership-blog/how-frequently-should-i-post-to-facebook

Jung, E. H., \& Sundar, S. S. (2016). Senior citizens on Facebook: How do they interact and why? Computers in Human Behavior, 61, 27-35. http://doi.org/10.1016/j.chb.2016.02.080

Kang, H., \& Sundar, S. S. (2016). When Self Is the Source: Effects of Media Customization on Message Processing. Media Psichology, 19(4), 1-28. http://doi.org/10.1080/15213269.2015.1121829

Kaushik, A. (2011). Best social media metrics: Conversation, amplification, applause, economic value. Retrieved 10 March 2017, from http://www.kaushik.net/avinash/best-social-media-metrics-conversationamplification-applause-economic-value/

Kemp, S. (2018). Digital in 2018: World's internet users pass the 4 billion mark. Retrieved 20 May 2018, from https://wearesocial.com/blog/2018/01/global-digital-report-2018

Kent, M. L. (2013). Using social media dialogically: Public relations role in reviving democracy. Public Relations Review, 39(4), 337-345. http://doi.org/10.1016/j.pubrev.2013.07.024

Ki, E.-J., \& Nekmat, E. (2014). Situational crisis communication and interactivity: Usage and effectiveness of Facebook for crisis management by Fortune 500 companies. Computers in Human Behavior, 35, 140-147. http://doi.org/10.1016/j.chb.2014.02.039 
Kim, S., Kim, S.-Y., \& Hoon Sung, K. (2014). Fortune 100 companies ' Facebook strategies: corporate ability versus social responsibility. Journal of Communication Management, 18(4), 343-362.

http://doi.org/10.1108/JCOM-01-2012-0006

Lee, S. (2016). How can companies succeed in forming CSR reputation? Corporate Communications: An International Journal, 21(4), 435-449. http://doi.org/10.1108/CCIJ-01-2016-0009

Li, T., Berens, G., \& Maertelaere, M. de. (2013). Corporate Twitter Channels: The Impact of Engagement and Informedness on Corporate Reputation. International Journal Of Electronic Commerce, 18(2), 97-126. http://doi.org/10.2753/JEC1086-4415180204

Linke, A., \& Zerfass, A. (2012). Future trends in social media use for strategic organisation communication: Results of a Delphi study. Public Communication Review, 2(2), 17-29. Retrieved from https://epress.lib.uts.edu.au/journals/index.php/pcr/article/viewFile/2736/3026

Losada-Díaz, J. C., \& Capriotti, P. (2015). La comunicación de los museos de arte en Facebook: comparación entre las principales instituciones internacionales y españolas. Palabra Clave, 18(3), 889-904. http://doi.org/10.5294/pacla.2015.18.3.11

Luarn, P., Lin, Y.-F., \& Chiu, Y.-P. (2015). Influence of Facebook brand-page posts on online engagement. Online Information Review, 39(4), 505-519.

Macnamara, J. (2016). Organizational listening: Addressing a major gap in public relations theory and practice. Journal of Public Relations Research, 28(3/4), 146-169.

http://doi.org/10.1080/1062726X.2016.1228064

Mander, J. (2016). GWI SOCIAL SUMMARY: GlobalWebIndex's quaterly report on the latest trends in socia networking. Retrieved 24 June 2016, from http://www.globalwebindex.net/hubfs/GWI_Social__Q2_2016_Summary.pdf?t=1467106999259\&utm_campaign=Insight+Reports\&utm_source=hs_automation \&utm_medium $=$ email\&utm_content $=22078263 \& \_$hsenc=p2ANqtz--

AonKpQ8d8U0jAEwDhaAjZp03jSIqgNfs49heYCeEwyJNKmBJnCeH9BwBJM8TXV

Moreno, A., Molleda, J. C., Athaydes, A., Suárez, A. M., Herrera B., M. V., \& Álvarez Nobell, A. (2017). Latin American Communication Monitor 2016-2017. Tendencias en Comunicación Estratégica: big data, automatización, engagement, influencers,coaching y competencias. Resultados de una encuesta en 17 países. EUPRERA/DIRCOM. Madrid, España.

Narayanan, M., Asur, S., Nair, A., Rao, S., Kaushik, A., Mehta, D., ... Lalwani, R. (2012). Social media and business. Vikalpa: The Journal for Decision Makers, 37(4), 69-111.

http://doi.org/10.1016/j.orgdyn.2015.12.006

Neill, M. S., \& Moody, M. (2015). Who is responsible for what? Examining strategic roles in social media management. Public Relations Review, 41(1), 109-118. http://doi.org/10.1016/j.pubrev.2014.10.014

Noguera Vivo, J. M. (2010). Redes sociales como paradigma periodístico . Medios españoles en Facebook. Revista Latina de Comunicación Social, 65, 176-186. http://doi.org/10.4185/RLCS-65-2010-891-176-186

Parveen, F., Jaafar, N. I., \& Ainin, S. (2014). Social media usage and organizational performance: Reflections of Malaysian social media managers. Telematics and Informatics, 32(1), 67-78.

http://doi.org/10.1016/j.tele.2014.03.001

Patel, N. (2016). How Frequently You Should Post on Social Media According to the Pros. Retrieved 21 June 
2017, from https://www.forbes.com/sites/neilpatel/2016/09/12/how-frequently-you-should-post-on-socialmedia-according-to-the-pros/\#4356de7e240f

Pérez-Dasilva, J., Genaut-Arratibel, A., Meso-Aierdi, K., Mendiguren-Galdospín, T., Marauri-Castillo, I., Iturregui-Mardaras, L., ... Rivero-Santamarina, D. (2013). Companies on Facebook and Twitter . Current situation and communication strategies. Revista Latina de Comunicación Social, 68, 676-695.

http://doi.org/10.4185/RLCS-2013-996en

Pletikosa Cvijikj, I., \& Michahelles, F. (2013). Online engagement factors on Facebook brand pages. Social Network Analysis and Mining, 3(4), 843-861. http://doi.org/10.1007/s13278-013-0098-8

Quintly. (2016). Brand Study HI 2016: How do 30 of the biggest brands use Facebook? Retrieved from https://www.quintly.com/blog/2016/10/30-biggest-brands-on-facebook-analyzed-in-depth/

Serrano-Cobos, J. (2016). Tendencias tecnológicas en internet: hacia un cambio de paradigma. El Profesional de La Información, 25(6), 843-850. http://doi.org/10.3145/epi.2016.nov.01

Shih, C. C. (2009). The Facebook Era: Tapping Online Social Networks to Built Better Products, Reach New Audiences, and Sell More Stuff. (M. Taub, Ed.). USA: Prentice Hall.

Shin, W., Pang, A., \& Kim, H. J. (2015). Building Relationships Through Integrated Online Media: Global Organizations' Use of Brand Web Sites, Facebook, and Twitter. Journal of Business and Technical Communication, 29(2), 184-220. http://doi.org/10.1177/1050651914560569

Sixto Garcia, J., Aguado Dominguez, N., \& Riveiro Castro, R. (2017). Presencia 2.0 de las pymes gallegas: niveles de participación y engagement con los usuarios. Revista Latina de Comunicación Social, 72, 47-68. http://doi.org/http://dx.doi.org/10.4185/RLCS-2017-1153es

Sprout Social. (2016). Turned Off: How Brands Are Annoying Customers on Social. THE Q3 2016 SPROUT SOCIAL INDEX. Retrieved from http://downloads.sproutsocial.com/The-Q3-2016-Sprout Social-IndexSprout-Social.pdf

Statista. (2017). Average number of weekly posts on social media in the U.S. 2015. Retrieved 15 May 2017, from https://www.statista.com/statistics/620974/average-number-brand-posts-social-media/

Statista. (2018). Ranking mundial de los 10 países con más usuarios de Facebook a fecha de abril de 2018 (en millones). Retrieved 20 May 2018, from https://es.statista.com/estadisticas/518638/ranking-de-los-paises-conmas-usuarios-de-facebook-a-nivel-mundial/

Sundstrom, B., \& Levenshus, A. B. (2017). The art of engagement: dialogic strategies on Twitter. Journal of Communication Management, 21(1), 17-33. http://doi.org/10.1108/JCOM-07-2015-0057

Taylor, M., \& Kent, M. L. (2014). Dialogic Engagement: Clarifying Foundational Concepts. Journal of Public Relations Research, 26(5), 384-398. http://doi.org/10.1080/1062726X.2014.956106

Valentini, C. (2015). Is using social media 'good' for the public relations profession? A critical reflection. Public Relations Review, 41(2), 170-177. http://doi.org/10.1016/j.pubrev.2014.11.009

Valerio Ureña, G., Herrera Murillo, D., Herrera Murillo, N., \& Martínez Garza, F. J. (2015). Propósitos de la comunicación entre empresas y sus seguidores en Facebook. Revista Latina de Comunicacion Social, 70, 110-121. http://doi.org/10.4185/RLCS-2015-1037 
van den Berg, A. C., \& Verhoeven, J. W. M. (2017). Understanding social media governance: seizing opportunities, staying out of trouble. Corporate Communications: An International Journal, 22(1), 149-164. http://doi.org/10.1108/CCIJ-06-2015-0035

Waddock, S. (2004). Parallel universes: Companies, academics, and the progress of corporate citizenship. Business and Society Review, 109(1), 5-42. http://doi.org/10.1111/j.0045-3609.2004.00002.x

Wang, Y. (2015). Incorporating Social Media in Public Relations : A Synthesis of Social Media-Related Public Relations Research. Public Relations Journal, 9(2007), 1-14.

Wissen, N. Van. (2017). Building Stakeholder Relations Online : How Nonprofit Organizations Use Dialogic and Relational Maintenance Strategies on Facebook. Communication Management Review, 2(April), 54-74. http://doi.org/10.22522/cmr20170119

Yang, S.-U., Kang, M., \& Cha, H. (2015). A Study on Dialogic Communication, Trust, and Distrust: Testing a Scale for Measuring Organization-Public Dialogic Communication (OPDC). Journal of Public Relations Research, 27(2), 175-192. http://doi.org/10.1080/1062726X.2015.1007998

How to cite this article in bibliographies / References

P Capriotti, I Zeler, A Oliveira (2019): "Dialogic communication 2.0. Analysis of interactions in Latin American organizations". Revista Latina de Comunicación Social, 74, pp. 1094 to 1113.

http://www.revistalatinacs.org/074paper/1373/56en.html DOI: $10.4185 /$ RLCS-2019-1373en

Paper received on 2 April. Acepted on 28 June. Published on 2 July. 